\title{
STEADFAST SAINTS OR MALLEABLE MODELS? SEVENTEENTH-CENTURY IRISH HAGIOGRAPHY REVISITED
}

BY

\author{
SALVADOR RYAN*
}

At one of the last sessions of the Council of Trent, the question of the role of saints within the Church was addressed. While the fathers upheld the value of venerating images and relics of the saints, they nevertheless admitted that there had been some abuses of their cults in the past. This led effectively to an effort to regulate and reform the process of canonization, by which saints were made, involving a greater control over the creation of saints by the authorities in Rome in order to avoid the further growth of dubious local cults that ranged from the benign to the bizarre. ${ }^{1}$ In other words, recognition of the sacred was centralized. ${ }^{2}$ In the wake of the Council, and amidst criticisms of the previously accepted view of sainthood from reformers within and without the Church alike, the official reaction of church authorities was indecisive. Thus, from the close of the Council in 1563 until 1588, when the Congregation of Sacred Rites and Ceremonies was established to oversee canonizations, there were no new saints officially recognized within the Catholic Church. ${ }^{3}$ One of the problems facing the Church was the prevalence of what was now considered to be questionable material in the lives of even the officially recognized saints. A more historically critical method of outlining the lives of saints was required if the idea of sainthood was going to retain any credibility in a rapidly changing

*Dr. Ryan is a Post-Doctoral Fellow of the Irish Research Council for the Humanities and Social Sciences (IRCHSS) at the Department of Modern History, National University of Ireland, Maynooth. He wishes to gratefully acknowledge the support of the IRCHSS in affording him the opportunity to complete the research that led to the final version of this article.

${ }^{1}$ For a discussion of one of the most bizarre cults of the medieval period see $\mathrm{J}$. C. Schmitt, The Holy Greybound: Guinefort, Healer of Children since the Thirteenth Century (Cambridge, 1983).

${ }^{2}$ Peter Burke, "How to be a Counter-Reformation saint," in Kaspar Van Greyerz (ed.), Religion and society in early modern Europe (London, 1984), pp. 46-47.

${ }^{3}$ Ibid., p. 46. 
Europe. In order to achieve this, the construction of new lives would have to attain certain standards and, concomitantly, old lives that were deficient in this area necessitated amendment. Peter Burke sees evidence of this new and more critical approach to the lives of saints in the work of Erasmus on the life of St. Jerome. ${ }^{4}$

It was, however, a Jesuit project, begun in Antwerp in 1607 and spearheaded by Father Heribert Rosweyde, that began a systematic attempt at collating and publishing what was hoped would be a more acceptable collection of the lives of the saints of the universal church. ${ }^{5}$ Rosweyde's Fasti sanctorum (1607), apart from giving an account of the manuscript lives of saints found in Belgian libraries, outlined a plan for the publication of eighteen volumes of the lives of the saints including a commentary volume and index volume. ${ }^{6} \mathrm{He}$ did not live to see his plan implemented, however, and when he died in 1629, John Bollandus was placed in charge of the project in his stead. ${ }^{7}$ The group that worked with John Bollandus, known since as the Bollandists, published in 1643 two volumes of the lives of saints whose feastdays occurred in January, followed in 1648 by three volumes treating of the saints whose feasts occurred in February. ${ }^{8}$ Roughly around the same time, in 1645 and 1647 respectively, to be precise, John Colgan, an Irish Franciscan friar based at Louvain, published two volumes of Irish saints' lives, the first, entitled Acta Sanctorum Hiberniae (1645), treating of the lives of Irish saints whose feast days occurred in January, February, and March, and the second, Triadis Thaumaturgae (1647), comprising various lives of Patrick, Brigid, and Colmcille.

The works of Colgan marked the culmination of a long process, involving many individuals, that partly entailed the production of Irish saints' lives that would satisfy the expectations of Tridentine prelates such as John Roche of Ferns, who praised the life of Patrick in the new breviary as "modern, drawn out of the best writers, more seemly to be read than the ancient legend." Renewed interest in the publication of

${ }^{4}$ Ibid.

${ }^{5}$ Canice Mooney, "Father John Colgan O.F.M.: His Work, Times and Literary Milieu," in Terence O'Donnell (ed.), Father John Colgan O.F.M. 1592-1658 (Dublin, 1959), p. 19; see also Richard Sharpe, Medieval Irish Saints' Lives: An Introduction to Vitae Sanctorum Hiberniae (Oxford, 1991), p. 40.

${ }^{6}$ Mooney, op. cit., p. 19.

IIbid.

${ }^{8}$ Ibid.

'Bernadette Cunningham and Raymond Gillespie, "'The most adaptable of saints': The Cult of St. Patrick in the Seventeenth Century," Archivium Hibernicum, XII (1996), 90-91. 
"more seemly" lives of Irish saints can be traced to the activity of Richard Stanihurst, whose Latin life of St. Patrick entitled De vita S Patricii, Hiberniae Apostoli was published at Antwerp in $1587 .{ }^{10}$ Based on both the works of Jocelin and Giraldus Cambrensis, this life also contained many additional patristic and biblical references that portrayed Patrick as a figure whose life was intimately related to the patriarchs in Scripture and the Fathers of the Church, therefore bestowing on him exceptional credentials. Printed at the most famous publishing house in Northern Europe, that of Christopher Plantin, it was dedicated to Alexander Farnese, duke of Parma and governor of the Spanish Netherlands. The emphasis in this work was deliberately placed on Patrick's successful work of evangelization in Ireland, where the roots of Ireland's contemporary loyalty were to be found. In dedicating the work to the governor of the Spanish Netherlands, Stanihurst implicitly identified Patrick's mission with that of the Spanish campaign aimed at wiping out heresy that was currently active in the Low Countries. ${ }^{11}$ The work of other Old English scholars, such as Father Henry Fitzsimon (1566-1643) and Father Stephen White (1574-1646), both Jesuits, also had a formative influence on the hagiographical research of the Louvain school. Henry Fitzsimon, who had studied at various locations on the Continent, concerned himself with the compilation of Catalogus praecipuorum Sanctorum Hiberniae in $1611 .^{12}$ In the course of twenty years of research in various libraries, Fitzsimon stumbled upon a handwritten life of St. Patrick in Douai, presumably undiscovered heretofore. ${ }^{13}$ His work was widely consulted by other scholars such as James Ussher, and was also passed on to the Franciscan Father Hugh Ward (1593-1635), a native of Donegal, who resided at Louvain. ${ }^{14}$ Father Rosweyde also possessed an expanded copy, which was used later by the Bollandists. ${ }^{15}$ The Bollandists were especially indebted to the work of Father Stephen White, S.J. Holding professorships at Ingolstadt and

${ }^{10}$ Ibid., p. 88.

${ }^{11}$ Ibid.; also Colm Lennon, "Taking Sides: The Emergence of Irish Catholic Ideology," in Vincent P. Carey and Ute Lotz-Heumann (eds.), Taking Sides: Colonial and Confessional Mentalités in Early Modern Ireland (Dublin, 2003), pp. 84-86.

${ }^{12}$ Sharpe, op. cit., p. 42. This work was, itself, based on a list of ninety-four names, drawn up by Father Richard Fleming, S.J., who served as chancellor of the university at Pont à Mousson, where Fitzsimon once studied.

${ }^{13}$ Ibid., p. 43.

${ }^{14}$ See Alan Ford, "James Ussher and the Creation of an Irish Protestant Identity" in B. Bradshaw and P. Roberts (eds.), British Consciousness and Identity (Cambridge, 1998), pp. 185-212; John McCafferty, "St. Patrick for the Church of Ireland: James Ussher's Discourse," Irish Studies Review, 6 (April, 1998), 87-101.

${ }^{15}$ Sharpe, op. cit., p. 43. 
Dillingen, White had access for many years to the manuscript collections of Germany, where he discovered many important texts, including Vita I S. Brigidae in a manuscript of St. Magnus in Regensburg. He was not slow to pass on copies of what he found to James Ussher, the Franciscans at Louvain, and the Bollandists. ${ }^{16} \mathrm{He}$ had been in regular correspondence with Father Rosweyde since 1607, and the Bollandists relied very much on White for the compilation of their sections on the Irish saints. ${ }^{17}$

The hagiographical project of the Franciscans at Louvain, inspired by the developing interest elsewhere in saints' lives, can be said to have begun in earnest in March, 1623. Father Patrick Fleming (1599-1631), a Franciscan and a native of Louth, was traveling from Louvain to Rome to attend the general chapter of the order, in the company of his confrère, Aodh Mac Aingil (known in English as Hugh McCaghwell), while at the same time Father Hugh Ward was journeying from Salamanca to Louvain. The three friars met Father Thomas Messingham, rector of the Irish College in Paris, while passing through that city. Messingham was, at that time, preparing a work on the lives of the Irish saints in Latin. ${ }^{18}$ Both Ward and Fleming promised to assist Messingham in his work by forwarding to him copies of the lives of the Irish saints that they might stumble upon on their journey. ${ }^{19}$ Letters written from Fleming to Ward, after the former's arrival in Rome, detail how both he and Mac Aingil traveled from one archive to another in the quest for new material on the Irish saints. ${ }^{20}$ Although Messingham acknowledged in his publication, Florilegium Insulae Sanctorum (1624), that he received a copy of a hymn and of the Rule of St. Columban from Aodh Mac Aingil, ${ }^{21}$ Hugh Ward later accused Messingham of publishing many items for which he was indebted to the Franciscans, without acknowledging their contribution to the enterprise. ${ }^{22}$ The arrangement with Messingham, therefore, fell through shortly afterwards, and Fleming and Ward pressed on with the project themselves.

${ }^{16}$ Ibid., p. 45.

${ }^{17}$ Ibid., p. 44.

${ }^{18}$ Mooney, op. cit., p. 15.

${ }^{19}$ Ibid.

${ }^{20}$ Cathaldus Giblin, "Hugh McCaghwell, OFM, Archbishop of Armagh (†1626): Aspects of His Life," in Benignus Millet and Anthony Lynch (eds.), Dún Mbuire Killiney 1945-95: léann agus seanchas (Dublin, 1995), p. 92.

${ }^{21}$ Ibid.

${ }^{22}$ Mooney, op. cit., p. 16. 
The arrival of Mícheál Ó Cléirigh, a man in his mid-forties and a native of Donegal, to St. Anthony's College, Louvain, in late 1623 or early 1624 gave the enterprise new impetus. ${ }^{23}$ Fleming urged Ward to send Ó Cléirigh, who, while ignorant of Latin, was nevertheless skilled in Irish, back to Ireland to collect as many manuscripts as possible and copy as many saints' lives as he could manage. ${ }^{24}$ By the beginning of 1629 , Ó Cléirigh claimed to have collected more than three or four hundred lives. ${ }^{25}$ These lives were carried back to Louvain, where Ward and his assistants began to translate them into Latin. ${ }^{26}$ John Colgan (1592-1658) was placed in charge of the project after the deaths of both Fleming and Ward, in 1631 and 1635 respectively, and he set about completing their work. ${ }^{27}$ On completion of the Acta Sanctorum in 1645, Colgan was munificent in acknowledging his indebtedness to Ward, Fleming, Ó Cléirigh, and others, himself claiming to have done no more than "add the chapter numbers, marginals, explanations or notes to each Life." ${ }^{28}$ In reality, however, his editorial work was comprehensive and learned, and the second volume, dedicated to the three patron saints of Ireland, was accomplished largely by Colgan himself. ${ }^{29}$ Having intended to publish seven or eight volumes in all, Colgan's work was interrupted by his death in $1658 .^{30}$

Renewed interest in hagiography in the seventeenth century, especially in Irish hagiography by Irish scholars on the continent, cannot be attributed to any one factor. It would be overly simplistic to cite the stricter regulations governing the canonization of individuals, operational in the Sacred Congregation for Rites and Ceremonies, as solely responsible for the desire, on the part of many scholars, to remodel existing saints' lives in order to make them more acceptable to a Tri-

${ }^{23}$ Sharpe, op. cit., p. 49.

${ }^{24}$ Ibid., p. 50; Mooney, op. cit., p. 16. Ó Cléirigh most probably reached Ireland in the autumn of 1626: Cathaldus Giblin, "The Annals of the Four Masters," in Millett and Lynch (eds.), op. cit., p. 137.

${ }^{25}$ Sharpe, op. cit., p. 51.

${ }^{26}$ Mooney, op. cit., p. 16.

${ }^{27}$ Ibid., pp. 21-22. For a survey of Colgan's life see pp. 7-13. It seems that Colgan had some involvement in the project since 1628 , when he was presumably lecturing in theology in Germany. A letter written to Ward in the same year indicates that he was about to be transferred to Mainz for a teaching post in theology there: Sharpe, op. cit., p. 54; Mooney, op. cit., p. 12.

${ }^{28}$ Sharpe, op. cit., p. 55.

${ }^{29}$ Ibid., pp. 55-56.

${ }^{30}$ Mooney, op. cit., p. 26. 
dentine audience. Although there is evidence to suggest that this certainly constituted one reason for focusing anew on hagiography, there were other important issues involved. At least four principal factors, influencing Irish hagiographical projects in the first half of the seventeenth century, can readily be identified. The first factor was influenced by the political fallout of the conquest of Ireland, and constituted an effort to seek out and preserve a large body of hagiographical material, extant in either manuscript or oral form, before it disappeared forever. The second entailed an employment of the lives of the saints to edify, instruct, and spiritually enrich the Catholic faithful. The third consisted of a defense of Irish history and a refutation of what was considered to be an attempt by the Reformers to utilize native saints for their own advantage. The fourth involved a process already noted, whereby lives of Irish saints were remodeled to meet new and more stringent requirements and also to compete favorably with their European counterparts. An examination of each of these in turn is necessary in order to comprehend better why these hagiographical projects cannot be viewed as homogeneous either in purpose or in implementation. The first two factors, although no less important, require shorter treatment and are summarily discussed below while the third and fourth factors are afforded more detailed analysis.

The first factor influencing the great hagiographical project of the Irish Franciscans at Louvain was the awareness that a body of manuscript sources was in danger of being lost forever because of the political situation in seventeenth-century Ireland. The claim of the Four Masters, ${ }^{31}$ in their introduction to The Annals of the Kingdom of Ireland (popularly known as the "Annals of the Four Masters"), that they undertook the work to save the records of the Irish past from oblivion, could also be understood as one of the principal reasons for their other works, including Félire na Naomb nÉrennach (also known as the "Martyrology of Donegal"), the Leabbar Gabbála ("The Book of Invasions of Ireland"), and Réim Ríoghraidbe na bÉreann agus Seanchas a Naomb (Genealogiae Regum et Sanctorum Hiberniae), all of which were completed in the space of a decade. ${ }^{32}$ In fact, Mícheál Ó Cléirigh's brief, which was to copy, among other things, all the lives of the saints that he could find in Ireland, obliged him to record exactly what he

\footnotetext{
${ }^{31}$ Mícheál Ó Cléirigh, Cúcoigríche Ó Cléirigh, Fearfeasa Ó Maolchonaire, and Cúcoigríche Ó Duibhgennáin.

${ }^{32}$ Bernadette Cunningham, "The Culture and Ideology of Irish Franciscan Historians at Louvain, 1607-50," in Ciaran Brady (ed.), Ideology and the Historians: Historical Studies, XVII (Dublin, 1991), 17; see also Giblin, “The Annals of the Four Masters," p. 137.
} 
found, without emendation. This was a duty that even he himself found difficult. Bernadette Cunningham explains that

he repeatedly expressed a desire to be more critical in his use of the available material than the instructions of his Louvain-based superiors allowed. He had been dispatched to Ireland to assemble, not to distil, and thus included material which he was convinced was not historical. ${ }^{33}$

A similar preoccupation with recording exactly what he found can be seen in the work of John Colgan. For his Acta Sanctorum Hiberniae (1645), Colgan treated his sources in the following manner. If a Latin life of the saint existed, it was invariably published as it was found. If the life was in Irish, it was translated into Latin. In the case of two very similar lives, Colgan used what he deemed to be the original. If many different lives of the saint were available, all were printed. ${ }^{34}$ He applied the same policy in his second major work, Triadis Thaumaturgae (1647), detailing the lives of SS. Patrick, Brigid, and Columcille. This work contained no less than seven lives of Patrick, six of Brigid, and five of Columcille. ${ }^{35}$ Ludwig Bieler concludes, therefore, that the Triadis Thaumaturgae "aim[ed] at nothing less than a complete dossier of each of the three saints, that is to say, at a collection of all relevant texts and references concerning them." ${ }^{36}$ Colgan's tendency to err on the side of completeness resulted in his being less critical in his treatment of the sources than others, such as Stephen White, S.J., would have liked. ${ }^{37}$ Canice Mooney, in an assessment of Colgan's lack of criticism in the hagiographical sphere, attributes this approach to an unquestioning respect for the saints:

His reverence for God's saints made him hesitant about casting doubts on alleged miracles. The fallacy lay in confusing reverence for the saints with respect for imaginative and fallacious accounts of their lives. ${ }^{38}$

Both the Acta Sanctorum Hiberniae and Triadis Thaumaturgae acted as dossiers of all the available material on the lives of the Irish saints. This material was sourced and its contents could therefore be traced to a particular author or Life, thus presenting the "evidence" for the feats of the saints before a European audience. In the preface to Triadis

${ }^{33}$ Cunningham, op. cit., p. 18.

${ }^{34}$ Mooney, op. cit., pp. 34-35.

${ }^{35}$ Ibid., p. 35.

${ }^{36}$ Ludwig Bieler,"Trias Thaumaturga 1647," in Terence O'Donnell (ed.), Father John Colgan OFM, 1592-1658: Essays in Commemoration of the Third Centenary of his Death (Dublin, 1959), p. 42.

${ }^{37}$ Sharpe, op. cit., p. 60.

${ }^{38}$ Mooney, op. cit., p. 31 . 
Thaumaturgae, Colgan explained that the virtues of these wonderful Irish saints, often ridiculed by heretics, required a proper presentation of their relevant documentation and sources. ${ }^{39}$ The business of paring down the more fantastic details of saints' lives to make them more plausible to a European audience, then, was not one of Colgan's chief concerns. This was something that was left to others to worry about.

The second ambition affecting the compilation of Irish saints' lives in the first half of the seventeenth century was to instruct and edify a particular audience by raising up the saints as models to be imitated. The three most obvious models that the Irish writers on the Continent presented to their audience in Ireland for imitation were SS. Patrick, Brigid, and Columcille. Aodh Mac Aingil, in his tract on penance entitled Sgáthán Shacramuinte na hAithridhe (1618) employs on a number of occasions the example of these saints to urge his audience, whom he addresses as "a chlann chroidhe Phádruig," ${ }^{40}$ to revitalize their spiritual lives, arguing in the following manner:

Ós ó Phádruig do ghlac tú creideamb Chríosd, bíodh a bheatha, beatha na naomb do lean é 'na sgáthán at fhiaghnuisi dod chor féin a ccéim éigin a ccosmbuile riú. ${ }^{41}$

Mac Aingil states that there is much proof of the prayer, abstinence, and penance exercised by the three patrons, and especially by St. Patrick, encouraging his audience to read their lives ${ }^{42}$ Robert Rochford, in his 1625 edition of the lives of SS. Patrick, Brigid, and Columcille, also admits that it was the "desire of aduancing thy spirituall profit" that led him to undertake the work in the first instance. ${ }^{43}$ Part of the spiritual regeneration that the lives of the saints were employed to bring about involved a defense of the Catholic faith, and particularly those aspects of it that were disputed by Protestants. Rochford, in his epistle dedicatory, therefore, juxtaposes the views of the reformers with those of Patrick,

\footnotetext{
${ }^{39}$ Cunningham and Gillespie, op.cit., p. 95.

40"family of the heart of Patrick": Aodh Mac Aingil, Sgáthán Shacramuinte na bAithridhe, ed. Cainneach Ó Maonaigh, (Dublin, 1952), p. 191.

41" Since it was from Patrick that you accepted the Christian faith, let his life and the lives of the saints that followed him be a mirror before you to make you somewhat like them": ibid., pp. 130-131.

${ }^{42}$ Ibid., pp. 126-127.

${ }^{43}$ Robert Rochford (B.B.), The life of the glorious bishop S. Patricke apostle and primate togeather with the lives of the holy virgin Bridgit and of the glorious abbot S. Columbe patrons of Ireland (1625), facsimile reprint in D. M. Rogers (ed.), English Recusant Literature 1558-1640, Vol. 210 (London, 1974), p. xix.
} 
exemplified in his life. While the Reformers believed that kings were rulers of the church in their own dominion, Patrick accepted his mission from the See of Peter. While Reformers understood the Eucharist as symbol, Patrick confessed the Body and Blood of Christ, shrouded beneath symbols. The Reformers rejected the veneration of relics, whereas Patrick carried many relics of the apostles and martyrs back to Ireland from Rome, and so on. ${ }^{44}$ Geoffrey Keating, in his Tri biorghaoithe an bháis, completed before 1631, also encouraged his readers to have recourse to the examples of the Irish saints, citing their lengthy penances and good works. ${ }^{45}$

The interest shown in systematically recording and editing the various lives of Irish saints must, of course, be seen in the context of a renewed interest in ecclesiastical history as a whole in the wake of the Reformation, which leads us to the third factor influencing the renewed interest in Irish saints' lives. ${ }^{46}$ Flacius Illyricus's Magdeburg Centuries (1559-1574), a Protestant work treating of the history of Christianity from its inception to the beginning of the fourteenth century, constituted a scathing attack on Catholicism, to which Catholic apologists such as Cesare Baronio (Baronius) replied, after meticulous research in the Vatican archives, in his multi-volume work, Annales ecclesiastici a Christo nato ad annum 1198 (1588-1607). ${ }^{47}$ Such exchanges concerning the history of the universal Church were mirrored in disputations regarding ecclesiastical history in Ireland. In order to countenance the somewhat unsavory views of pro-English Catholic commentators such as Richard Stanihurst ${ }^{48}$ and Edmund Campion, the Irish Franciscan communities at Louvain and Rome wished that a comprehensive history of Ireland might be compiled. It never came to fruition, however, and such an enterprise was finally left to the Old English priest and scholar, Geoffrey Keating, who completed his Foras Feasa ar Érinn

${ }^{44}$ Ibid., pp. $\mathrm{x}-\mathrm{xi}$.

${ }^{45}$ Osborn Bergin (ed.), Tri bior-ghaoithe an bháis: the three shafts of death (Dublin, 1931), p. 72.

${ }^{46}$ Mooney, op. cit., pp. 13-14.

${ }^{47} I$ Ibid., p. 14.

${ }^{48}$ The early writing of Stanihurst contained less than flattering accounts of native Irish culture and customs. His later position vis à vis the Gaelic Irish was somewhat less critical as he saw the native Irish as valuable allies in the Catholic alliance. See Colm Lennon, Richard Stanihurst the Dubliner (Dublin, 1981), pp. 88-98; also Vincent P. Carey, "Neither good English nor good Irish': Bi-lingualism and Identity Formation in SixteenthCentury Ireland," in Hiram Morgan (ed.), Political Ideology in Ireland, 1541-1641 (Dublin, 1999), pp. 45-62. 
around $1634 .{ }^{49}$ Works dealing with more recent political history in Ireland from a Catholic perspective included Peter Lombard's De regno Hiberniae, sanctorum insula commentarius (completed in 1600 and published posthumously in 1632), Stephen White's Apologia pro Hibernia adversus Cambri calumnias (1615), David Rothe's Analecta sacra (1616-1619), and Philip O' Sullivan Beare's Historiae catbolicae Iberniae compendium (1621)..$^{50}$ The views of James Ussher, Protestant primate of Ireland (1625-1656), concerning the history of the Irish Church, were expressed in his Discourse of the religion anciently professed by the British and Irish (1631). He claimed that from the sixth to the twelfth century the Irish Church was free from the influence of Rome, and therefore flourished. He saw the twelfth-century reform, which extended Roman control over the Irish Church, as its death knell, leading to all manner of corruption..$^{51}$ Geoffrey Keating, in his Foras Feasa ar Éirinn (c. 1634), while declining to confront Ussher openly on this point, nevertheless highlighted the twelfth-century reform as a key moment in Irish Church history, which gave rise to the current ecclesiastical structures within which he lived his priesthood, thus implicitly rejecting Ussher's claim that it had led to a corrupt establishment..$^{52}$ Other works, such as Thomas Messingham's Florilegium sanctorum seu vitae, et acta sanctorum Hiberniae (1624), endeavored to provide a favorable presentation of Ireland's Christian past to a European audience..$^{53}$

Perhaps one of the most immediate challenges for Catholic writers in the first half of the seventeenth century was to dismiss the view, advocated by writers belonging to the Reformed Church, that St. Patrick was in fact a proto-Protestant..$^{54}$ This argument was most comprehensively

${ }^{49}$ Mooney, op. cit., pp. 15, 17; Bernadette Cunningham, The World of Geoffrey Keating: History, Myth and Religion in Seventeenth-Century Ireland (Dublin, 2000), p. 3.

${ }^{50}$ Mooney, op. cit., p. 17, n. 25. Peter Lombard was Catholic archbishop of Armagh, and David Rothe (1573-1650) served as Catholic bishop of Ossory; Stephen White, Apologia pro Hibernia adversus Cambri calumnias, ed. Matthew Kelly (Dublin, 1849).

${ }^{51}$ Cunningham, "The culture and ideology of Irish Franciscan historians at Louvain," p. 11.

${ }^{52}$ Cunningham, The World of Geoffrey Keating, pp. 119-120; eadem, "The culture and ideology of Irish Franciscan historians at Louvain," pp. 12-13.

${ }^{53}$ Cunningham, The World of Geoffrey Keating, p. 27. See Thomas O'Connor, "Towards the invention of the Irish Catholic Natio: Thomas Messingham's Florilegium (1624)," Irish Theological Quarterly, 64 (1999), 157-179.

${ }^{54}$ Bridget McCormack, Perceptions of St. Patrick in Eighteenth-Century Ireland (Dublin, 2000), p. 21. These views were expressed by Meredith Hanmer, who was dean of 
made by James Ussher. The Protestant primate maintained that since the early Church in Ireland was not under Roman influence

the religion professed by the ancient bishops, priests, monks and other Christians in this land, was for substance the very same with that which now by public authority is maintained therein against the foreign doctrine brought in thither in later years, by the Bishop of Rome's followers. ${ }^{55}$

The views of Ussher involved him in a protracted dispute on the matter with the Catholic bishop of Ossory, David Rothe. ${ }^{56}$ The claim appeared all the more grievous on account of simultaneous efforts by Catholic writers such as Thomas Messingham to portray Patrick not only as Catholic but, furthermore, as a Tridentine prelate, as is evidenced by the frontispiece to his Florilegium (1624), which depicted the saint in baroque vestments. ${ }^{57}$ Robert Rochford (B.B.), the Franciscan compiler of The life of the glorious bishop S. Patricke apostle and primate togeather with the lives of the boly virgin Bridgit and of the glorious abbot S. Columbe patrons of Ireland (1625), which was clearly aimed at an Old English audience, ${ }^{58}$ addressed this issue in the introduction to his work. ${ }^{59}$

He liued an hundred and two and twenty yeares, most part of which tyme he spent in reclayming the Irish from idolatry to the agnition of one true God: during the course of so many yeares so fruitfully spent among us, his pen neuer deliured, his tongue neuer uttered, nor himself neuer practised indeed any thing that might haue the least colour of fauouring or establishing that Religion, which the preachers of the fift Ghospel proudly vaunt, and vainely boast, to be the doctrine and fayth of the Primitiue Church. And since they obtrude their new found Ghospell on you, under the specious vizard of ven-

St. Patrick's in the late sixteenth century, in his Chronicle of Ireland, written in 1571: Cunningham and Gillespie, op. cit., p. 92.

${ }^{55}$ James Ussher, Discourse on the religion anciently professed by the Irish and British (Dublin, 1631; 2nd ed., 1739), p. 2.

${ }^{56}$ William O'Sullivan,"The correspondence of David Rothe and James Ussher 1619-23," Collectanea Hibernica, XXXVI (1994), 7-49. James Ussher already published in 1622 his Discourse of the religion anciently professed by the Irish and Scottish in Sir Christopher Sibthorpe, A friendly advertisement to the pretended catholics of Ireland ... in the end whereof is added an epistle written to the author of the religion anciently professed by the Irish and Scottish by James Ussher (Dublin, 1622; 2nd ed., 1623); see Cunningham and Gillespie, op. cit., pp. 92, 103.

${ }^{57}$ McCormack, op. cit., p. 23.

${ }^{58}$ Cunningham and Gillespie, op.cit., p. 92.

${ }^{59}$ Rochford (B.B.), op. cit. 
erable antiquity; loe we offer heere S. Patricke's life... who liued in the purer times of Christianity, let them examine it, let them search it, \& point vs out what they shall find in it to coūtenance their cause, or to aduance their religion: but sure I am they will shrincke from such a disquisition, as would turne to their notable preudice and open confusion, by discouering the fondness and nouelty of their religion. ${ }^{60}$

Rochford continues by alluding to the many features of the life of Patrick that would "sound very harshly in Protestants eares." ${ }^{61}$ These include references to "quires of sacred virgins . . . troupes of holy monkes . . . holy vayles . . . ecclesiasticall tonsure . . holy water . . vessels of holy oyles . . . hallowed fire . . the signe of the crosse . . \& alibi." ${ }^{62}$ Rochford makes reference to how the above elements of a saint's life contrast with the experiences of the "wiuing ghospellers" who "hold no commerce, or society with a continēt and chast monke" and can make no sense of a saint's "short and broken sleepes taken all alone on a hard flint" when they, themselves, "lie immersed in beds of downe, not alone, but embracing their sweet harts with greater deuotion than euer any Genua Bible." ${ }^{63}$

The practice of contrasting the lives of ascetical and chaste Irish saints with indulgent and uxorious Reformed clergymen was not entirely new and can be traced to the poetry of the Franciscan, Eoghan Ó Dubhthaigh, in the late sixteenth century. Addressing the Protestant bishops Sheyne, Casey, and McGrath, Ó Dubhthaigh invites them to model themselves on Patrick's life while simultaneously indicating how removed their own lives are from the life of the saint:

Remember St Patrick's pilgrimage on the Reek; look at his fasting in the cave. If the clergy of the present day attain heaven, that son of Calpurn was a nincompoop! $!^{64}$

Aodh Mac Aingil quotes this verse of Ó Dubhthaigh's in Sgátbán Shacramuinte na bAitbridbe and adds, "Má táidsion [the Reformed clergy] ar shlighidb fblaitbeambnuis, do bbi Pádruig 'na amadán ar seachrán nó 'na chluanaire chealgach , do tharraing sinne 'na dbi-

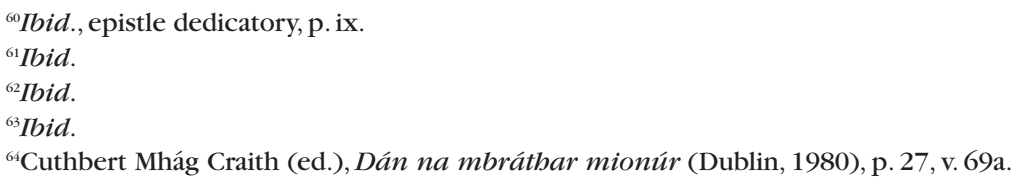


aigh lé bainbbfios nó lé cealguibb ..." ${ }^{55}$ This pronouncement of Mac Aingil's followed a passage where the penitential lives of Patrick, Brigid, and Colmcille, and all the saints of Ireland were contrasted with the selfsatisfying and luxurious lives of the "new clergy." While the saintly clergy of Ireland's past performed "penance without fault," the new clergy commit "fault without penance." Whereas, the saints offered the sacrifice of the Lamb of God in the Mass, the new clergy perform the "filthy supper of lustful Calvin." He concludes by stating that the dissimilarity between God and the devil is hardly greater than that between the two sets of clergy ${ }^{66}$ The business of reclaiming Patrick as a Catholic saint and not a proto-Protestant was therefore not confined to works addressed to the Old English of the Pale but also to the Gaelic Irish as evidenced by the passages from the works of Ó Dubhthaigh and Mac Aingil. There were, however, some voices addressing the Gaelic world that unwittingly compromised Patrick's credentials as a saint of the Roman Church in an attempt to remain faithful to Gaelic lore. One such voice was that of Geoffrey Keating, who, while acknowledging the value of the twelfth-century reform of the Irish Church, nevertheless stated that "the Roman pontiff never had definite authority over Ireland, any more than he had over Spain and France." ${ }^{67}$

One of the most pressing concerns of Irish Catholic writers in the first half of the seventeenth century was to refute the claims made by a group of Scottish scholars that in both the early and later medieval period the word Scotia meant Scotland and Scotus a Scotsman. ${ }^{68}$ The debate had begun on the Continent in the course of research on the lives of the early Irish saints. One of the first to publish on the subject was Henry Fitzsimon, S.J., in his Catalogus praecipuorum Sanctorum Hiberniae (1619), in which he defended Ireland's claim to her saints. ${ }^{69}$ The most famous protagonist of the view that many of the early "Irish" saints were in fact Scottish, was Thomas Dempster, who published both Nomenclatura Scotorum scriptorum and Scotia illustrior, seu mendicabula repressa, modesta parechasi Thomae Dempsteri in $1620 .^{70}$

\footnotetext{
${ }_{65}^{6}$ "If they [the Reformed clergy] are on the way to heaven Patrick was a misguided fool or a treacherous deceiver, and he brought us after him by ignorance or deceit": Aodh Mac Aingil, Sgáthán Shacramuinte na bAitbridbe, p. 132.

${ }^{66}$ Ibid., p. 131.

${ }^{67}$ McCormack, op. cit., p. 24.

${ }^{68}$ Mooney, op. cit., p. 17.

${ }^{69}$ Cunningham, The World of Geoffrey Keating, p. 86, n. 24.

${ }^{70}$ Ibid., n. 25; see also Mooney, op. cit., p. 18.
} 
This was quickly followed by a rebuttal of Dempster's claim by the Catholic bishop of Ossory, David Rothe, in his Hibernia Resurgens (1621). ${ }^{71}$ The debate proved to be intense. Irish figures on the Continent were loath to allow the reputation of their homeland to be compromised by the Scottish claims, especially at this important juncture for the Church, at which the country's reputation in Catholic Tridentine Europe depended on the reliability of their saints' credentials. ${ }^{72}$ The magnitude of the implications for the Irish Church of this controversy provided added impetus for Franciscan scholars such as Patrick Fleming and Hugh Ward to join the search for hagiographical records with which Dempster might be discredited and defeated. ${ }^{73}$ The eagerness with which the Franciscans at Louvain defended their native saints also influenced Aodh Mac Aingil's publications on John Duns Scotus, on whose writings he had considerable expertise. In his 1620 edition of the commentaries of Duns Scotus, Mac Aingil included a Life of Scotus and a defense of him against Abraham Bzowski, a Polish Dominican, who had treated Duns Scotus's writings with some disdain in his continuation of Baronius's Annales Ecclesiastici. ${ }^{74}$ Aodh Mac Aingil commented in this work on the nomenclature of Ireland and the location of Duns Scotus's birthplace..$^{75}$ Evidence that the debate over the title Scotia and its meaning continued for some years appears in a letter from Stephen White, S.J., to John Colgan, O.F.M., written at the end of January, 1640. At the time, White was residing in Dublin. In the letter, he explains to Colgan that the reason some of his historical writings have not been published is due to a lack of finance. With regard to one of his works, entitled Scoto-Caledonica Cornix deplumanda ab auibus orbis, comprised of five books, he explains:

In the . . volume ... I refute the false histories and interpretation of names by the Scots of Alba from start to finish, methodically, by plain arguments, and in addition I lay before any reader, who is not blind, proof that through the first nine centuries and more the name Scotia, whether used by Christians or

${ }^{71}$ Cunningham, The World of Geoffrey Keating, p. 27.

${ }^{72}$ Robert Rochford, in his address to the reader in the 1625 publication on the lives of SS. Patrick, Brigid, and Columcille, states that he has translated Adomnán's use of Scotia as Ireland in the lives "in regard that Ireland was anciently called Scotia by the conspiring confession and uniforme consent of all learned writers, and especially, because it is cleerer than midday that my author meaneth by the Latin word Scotia Ireland which he calls sometimes Scotia and sometimes Hibernia": Rochford (B.B.), op. cit., pp. xviii-xix.

${ }^{73}$ Sharpe, op. cit., p. 47.

${ }^{74}$ Giblin,"Hugh McCaghwell OFM, archbishop of Armagh," pp. 90-91.

${ }^{75}$ Mooney, op. cit., p. 17. 
pagans, Irish or foreigners, applied only to Ireland. Only later, perhaps from the early eleventh century, was the name used of both our Ireland and of Alba or Caledonia. ${ }^{76}$

It is no surprise that such a defense of the name Scotia for Ireland in the early period came from a man whose contribution to the collection of Irish hagiographical manuscripts on the Continent in the seventeenth century was unmatched. He continues later in the letter with a suggestion for the ongoing refutation of the claims of the Scots:

I warn you again of a matter, which I deem of great importance, as affording a very expeditious way of diminishing the credit of our adversaries, Dempster, Chambers, Boece, Major, Buchanan, etc. This is to urge at once each and every single writer known to you at home or abroad, present or absent, secular or religious, Dominicans, Augustinians, etc., never to allow to be printed anything, whether on a grammatical, philosophical, theological, historical or other subject, unless it bears on the title page these or similar words-'By the Rev. Father N.N., an Irishman or Old Scot'. The constant commemoration of Scotus Vetus will not merely irritate our adversaries, though in truth it ought not, but it will awaken in foreign readers at least a curiosity to enquire about the Old Scots and the more recent Scots of Alba. . . . ${ }^{77}$

The feverish search for manuscripts containing lives of the Irish saints owed much, then, to the provocation of Dempster and his school.

The fourth factor that led Irish scholars on the Continent into hagiographical research involved a certain remodelling of saints' lives in an effort to render them more acceptable to Tridentine standards and to allow them to compete favorably with other European saints for recognition within the universal Church. The Irish Franciscans at Louvain do not seem to have been interested in promoting the cults of new saints but, instead, focused on the earlier Irish saints, and especially on those cults that possessed adequate documentation with which to make their case. ${ }^{78}$ In fact, "antiquity implied significance, and continuity with the tradition of an 'island of saints and scholars' was the point at issue." This did not mean that more recent "saints" were completely ignored either. The cult of the martyrs was encouraged by the compilation of a list 
of those who died for the faith by the Franciscan bishop of Down and Connor, Conor O'Devany, who himself was executed in 1612. This followed on an earlier work by John Howlin, who entered the Jesuit order in 1583 and compiled a work detailing the martyrdom of forty-five Irishmen and Irishwomen who died from the mid 1570's to the late 1580's entitled the "Perbreve Compendium," which however, was never published. ${ }^{80}$

The Genealogiae Regum et Sanctorum Hiberniae, a genealogy of the kings and saints of Ireland, compiled by Mícheál Ó Cléirigh and his associates at the monastery of Athlone in $1630,{ }^{81}$ was important for the hagiographical project in so far as it traced the origins of the Irish saints and established their impeccable pedigree by arguing that the saints themselves came from a line of kings. In the words of Bernadette Cunningham, the Franciscan friars were eager to demonstrate that "Irish saints were no peasants." ${ }^{82}$ Before Irish saints could be made to compete with other European candidates, their newly published lives had to be seen to be traceable to a recognized and reputable source. Thomas Messingham, in his Florilegium Insulae Sanctorum (1624), therefore, includes a reprinted version of Jocelin's Life of St. Patrick from an edition published at Antwerp in 1514, of Adomnán's Life of St. Columcille, and of Cogitosus's Life of St. Brigid, the latter two being derived from an edition by Peter Canisius. ${ }^{83}$ Messingham's publication did not contain any new material on the three patron saints of Ireland. However, it did not contain any superfluous material either, and the information to be found therein could be traced to standard hagiographical works, rendering it accountable and available for inspection. Robert Rochford was equally careful in his 1625 edition of the lives of SS. Patrick, Brigid, and Columcille, to remain within the bounds of accountability and to display, in so far as was practicable, some degree of impartiality. Having extolled the virtues of Irish saints, claiming them to be virtually without peer in all of the Christian kingdoms, Rochford comments on the care with which he chose the sources for his work, and why:

\footnotetext{
${ }^{80}$ Lennon, "Taking sides," p. 87; see also Patrick J. Corish and Benignus Millett, The Irish Martyrs (Dublin, 2004).

${ }^{81}$ Pádraig de Brún, “Lámhscríbhinní Gaeilge Dhún Mhuire," in Benignus Millett and Anthony Lynch (eds.), Dún Mbuire Killiney 1945-95: léann agus seanchas, p. 148.

${ }^{82}$ Cunningham, "The culture and ideology of Irish Franciscan historians at Louvain," p. 22.

${ }^{83}$ Sharpe, op. cit., p. 46.
} 
And fearing to be branded with the soule note of adulation, to your worthy selues, or partiality to my deere Country, I will keep within compasse, so as I meane to produce nothing, but what hath beene deliuered from the pens of famous Authors, who either for their antiquity claime veneration, or for their learning deserue credit, or for their sanctity chalenge authority. Euery Author I will alleadge by name speaking in his genuine sense, if not in his proper wordes. $^{84}$

If the Irish saints' credentials could be attested, then their remarkable attributes could confidently be lauded on the European stage. The publication of lives, which could be sourced to reputable hagiographers, made this possible. And thus Rochford could claim that Ireland

hath exposed on the theatre of the Catholicke Church such firme pillars of fayth, such burning lights of Religion, such clear mirrours of perfection, such perfect paternes of sanctity \& such rare miracles of learning, that other Christian Kingdomes are so far from ouer-peering her that few peere her in flying so high a pitch of true glory. ${ }^{85}$

John Colgan, in the preface to Triadis Thaumaturgae (1647), also boasted that SS. Patrick, Brigid, and Columcille were Europe's outstanding saints in terms of virtue and miracles, and that if greater existed, he did not know of them. ${ }^{86}$ Nicholas Vernulaeus, historiographer to the King of Spain and professor of public eloquence at the university of Louvain, in praising John Colgan's first volume on the saints, Acta Sanctorum Hiberniae (1645), confirms that the intentions of Colgan and his associates were to promote the causes of the Irish saints on the continent and to render their lives acceptable to a European audience:

Well you have merited, O most learned Colgan, of heaven and earth, of your country and of the whole world. Others of your fellow countrymen have arisen in these times to vindicate in arms the Catholic religion. . . . You vindicate the saints of your country with your pen. . . Y Your glory will be that you restore her saints to the Island of Saints, that the Church accepts them, and that the world acknowledges them. ${ }^{87}$

${ }^{84}$ Rochford (B.B.), op. cit., p. iv. A similar concern for proper sourcing of materials was expressed by John Colgan in the preface to his Triadis Thaumaturgae (1647); see Cunningham and Gillespie, op. cit., p. 95.

${ }^{85}$ Rochford (B.B.), op. cit., p.iv.

${ }^{86}$ Cunningham and Gillespie, op. cit., p. 95. Aodh Mac Aingil, in his Sgátbán Shacramuinte na bAitbridbe (1618), argued that the lives of the saints of Italy, Spain, France, and Germany, which he claimed to have read, illustrated that they fell far short of the severity of penance endured by the Irish saints (p. 125).

${ }^{87}$ Mooney, op. cit., p. 26. 
In order to make the lives of the Irish saints acceptable to the new and more rigorous standards of the Tridentine Church, some adjustments to existing lives were going to be needed. In the case of the cult of St. Patrick, Bernadette Cunningham and Raymond Gillespie argue that Old English Counter-Reformation Catholics saw the need for revision of some of the traditional lives of Patrick when presenting his story to a Roman audience. Thus, in the new breviary of the universal Church, which was published in the 1630's, while Jocelin's twelfthcentury life is used as a basic source, large parts of it are, nevertheless, omitted, chiefly those sections dealing with "exotic miracles and his traditional role of judge of the Irish." ${ }^{8}$ The business of excising the more fantastic elements of Patrick's life was an important one, and was seen as crucial to the acceptance of his cult at an official level in the Church. Correspondence between Stephen White, S.J., and John Colgan, O.F.M., in January, 1640, attests to the continuation of concern for such matters, at least on White's behalf. White mentions in a letter to Colgan that he is delighted to hear of his progress and especially with the Féiliride, and states that he wishes that that book and Colgan's other works were in the hands of a European audience. His praise contains a warning, however:

Before this happens, as a friend, I warn you of a few things. One is that the lives of SS Ailbe, Declan and Gerald of Mayo, who are mentioned in the catalogue you sent me, are swarming (if the Lives you have are the same as those I have read here) with improbable fables, and contain things opposed not only to all that has been written, delivered by tradition, and believed about $\mathrm{St}$ Patrick, our Apostle, and about his legation to Rome and thence to Ireland, but contrary to the old and modern Martyrologies, and clearly conflicting with the undoubted statements of St Prosper of Aquitaine, and the Venerable Bede etc., as I at one time proved to demonstration. ${ }^{89}$

Interestingly, Jocelin's twelfth-century life of St. Patrick receives two different types of treatment at the hands of Tridentine Catholic hagiographers. While Thomas Messingham was happy to reprint Jocelin's life in toto in his Florilegium Insulae Sanctorum (1624), the account of St. Patrick in the Roman Breviary, based on the same Life, leaves large sections of it out. It must be remembered, however, that two very different types of publication are in question here. The kind of life required for the breviary differed significantly from that required for a work like

\footnotetext{
${ }^{88}$ Cunningham and Gillespie, op. cit., p. 91. The Breviary Reform Commission, which was established in 1629, had, as one of its consultants, the Franciscan Luke Wadding:ibid., p. 90.

${ }^{89}$ Sharpe, op. cit., p. 60.
} 
Messingham's. Firstly, there was the issue of length. What was required for the breviary was a succinct synopsis of the principal elements of the saint's life, including mention of the characteristics of the saint that made him or her conform to the model of sainthood advocated by the universal Church. It is no surprise, therefore, to find reference to his parents, education, prayer, his having been guided by an angel, his call to ministry, his preaching, and his penitential exercises. ${ }^{90}$ These were universally recognized components of what a saint's life should be like, and naturally they were given priority in any summary of a saint's life..$^{91} \mathrm{Had}$ a strict policy of omitting spurious miracles operated among those responsible for Patrick's life in the Roman Breviary, it would be surprising to find a concluding reference to Patrick having raised people from the dead being permitted at all. ${ }^{92}$ Messingham, in his Florilegium Insulae Sanctorum (1624), openly defended the extravagant miracles of Irish saints as indicative of the power of God working through them. In response to those who claimed preference for Scripture instead of extraordinary wonders, Messingham queried whether, given this preference, they would then choose to reject altogether the many miracles found throughout Scripture. ${ }^{93}$

A passage from the continentally-educated Philip O'Sullivan Beare's history of Ireland in the Elizabethan period, written in 1621, illustrates that, far from portraying St. Patrick as a model of Tridentine Catholicity, trimmed of the excesses of medieval characterizations, he presents a saint with more in common with folklore and legend than with Tridentine hagiographical trends:

O'Neill was so sorely vexed at the holy city of Armagh being contaminated by heretics that he determined to cut it off from provisions. . . St Patrick, however, the Patron and Guardian of Ireland, and who was the first to consecrate this city to God, would not put off the punishment of the crime which impiously defiled the sacred town with heretics. It is believed that he was the bishop who, clad in pontificals, frequently and plainly appeared to the English at night and threatened them; took away the iron tips of their spears . . . and extracted the bullets and powder from their guns. ${ }^{94}$

\footnotetext{
${ }^{90}$ Cunningham and Gillespie, op. cit., p. 91.

${ }^{91}$ For a discussion on what kind of person possessed the necessary qualifications for sainthood during the Counter-Reformation see Burke, "How to be a Counter-Reformation saint," pp. 49-53.

${ }^{92}$ Cunningham and Gillespie, op. cit., p. 91.

${ }^{93} \mathrm{O}$ 'Connor, op. cit., p. 168.

${ }^{94} \mathrm{O}$ 'Sullivan Beare, Ireland under Elizabeth: Chapters towards a bistory of Ireland in the reign of Elizabeth, ed. Matthew J. Byrne (Dublin, 1903), p. 92.
} 
Cunningham and Gillespie also mention Robert Rochford's abbreviated version of Jocelin's Life of Patrick, which formed the basis for the Patrician section of his 1625 publication, as a clear example of the adaptation of a text to meet Counter-Reformation standards. Fifty-four of the original ninety-six chapters were omitted from this publication, removing "some of the more fantastic miracles, especially the infancy miracles and the cursing episodes." ${ }^{95}$ There is evidence to suggest, however, that Rochford was not averse to publicizing the miracles of his saints, and in fact used Patrick's claim to miracles as an argument in favor of his gargantuan stature as a saint in the epistle dedicatory to his work on the three patrons:

His life which heere we offer you, will aboundantly teach how stupendious he was in perpetrating of miracles, how admirable in al kind of sanctimony, and how enflamed with the zeale of gaining soules. ${ }^{96}$

His own reasoning for having provided an abridged version of Jocelin's text is contained in the "Advertisements to the Reader":

First (gentle reader) I haue thee understand, that in this translation of S. Patricke's life, I haue followed Iocelinus of Tornesio, who had written it in Latin aboue 400 yeares agone, at the intreaty of S. Malachy, bishop of Conerthern, of the right Reuerend Father in God Thomas, Lord Primate of Ireland, \& of the honorable knight Syr Iohn de Curcy, as himself signifyeth in his preface, which togeather with many other celebrious and note-worthy thinges I haue willingly left out, contenting my selfe in this present edition to publish a summary abridgement of matters, that are most remarkable, and best befitting our tymes. If I learne that this, my labour will proue gratefull, I will God willing, put my hand to an entire edition. ${ }^{97}$

Again, it seems that the redactor was faced with having to choose the most salient parts of Jocelin's life for publication, and the omission of fifty-four of the original chapters resulted not so much from a decision that they were unsuitable as from the necessity of selecting material that best served his purpose. ${ }^{98}$ Rochford's proposed publication of an entire edition of Jocelin's, should the abridged version whet his audi-

${ }^{95}$ Cunningham and Gillespie, op. cit., p. 90.

${ }^{96}$ Rochford (B.B.), op. cit., epistle dedicatory, p. viii.

${ }^{97}$ Ibid., p. xvii.

${ }^{98}$ In fact it seems that Rochford wished to provide an English translation of Jocelin's Life for Old English Catholics of the Pale just as Thomas Messingham had provided access to Jocelin's Life for a continental audience and for all who were versed in Latin. 
ence's appetite, suggests that he had no particular qualms about disseminating some of its more far-fetched material at a later date. This is especially evident in his treatment of the life of Brigid.

Robert Rochford's account of St. Brigid is based on two sources. The first source is the Life of Cogitosus, who was most probably a religious of the Brigittine monastery of Kildare. ${ }^{99}$ This life is thought to date from not much later than 650 and is considered to be the earliest Life of the saint. ${ }^{100}$ The second source used by Rochford is that of John Capgrave (1393-1464), an Augustinian friar, theologian, and historian based at Norfolk. Capgrave, having been indebted to the work of John of Tynemouth a century earlier, was responsible for the production of Nova Legenda Anglie, a comprehensive collection of saints' lives arranged in the fifteenth century. ${ }^{101}$

Rochford's use of Cogitosus's Life of Brigid as a source contains no evidence of the removal of its more fantastic elements which Cunningham and Gillespie draw attention to in his treatment of Jocelin's Life of Patrick. ${ }^{102}$ In fact, twenty-six of the thirty-one stories found in Cogitosus are included in Robert Rochford's account. ${ }^{103}$ The stories omitted by Rochford certainly cannot be categorized as Cogitosus's most implausible, and there seems to be no particular reason why they should have been left out. ${ }^{104}$ In fact, those that he chooses to incorporate are full of miraculous occurrences, including Brigid changing the course of a river, moving a huge tree that neither men nor oxen could stir, convert-

${ }^{99}$ Sean Connolly, “Cogitosus's Life of St Brigit: content and value," Journal of the Royal Society of Antiquarians Ireland, CXVII (1987), 5.

${ }^{100} \mathrm{Ibid}$; see also Donncha Ó hAodha (ed.), Bethu Brigte (Dublin, 1978), p. xxiv.

${ }^{101}$ See Carl Horstman (ed.), Nova Legenda Anglie: as collected by Jobn of Tynemouth, John Capgrave and others, and first printed, with new lives by Wynkyn de Worde a.d.maxvi, Vol. I (Oxford, 1902). Capgrave's life is itself an abridged version of the socalled Vita Prima, which comprised a conflation of various traditions about Brigid and was composed before the middle of the ninth century: ibid., p. 153, n. 5; see also Ó hAodha (ed.), Betbu Brigte, p. xx.

${ }^{102}$ Cunningham and Gillespie, op. cit., p. 90.

${ }^{103}$ Sean Connolly includes thirty-two chapters (or stories) in his edition of Cogitosus's work. However, since numbers three and thirteen are so similar in content I have treated them as one story, which is related in turn by Rochford. See Connolly, op. cit., pp. 12-13.

${ }^{104}$ One exception to this is the story wherein a woman, who had lost her virginity through youthful concupiscence and was now pregnant, came to Brigid for help. After Brigid's blessing, what had been conceived in her womb disappeared. Perhaps Rochford, fearing that this story would be open to misinterpretation, consciously omitted it: Connolly, op. cit., p. 16. 
ing stone into salt for the needy and water into beer for lepers, not to mention her hanging of a wet mantle on a sunbeam to dry. ${ }^{105}$ Neither was Rochford very selective about the passages he used from Capgrave. At Brigid's birth, the cloth covering her head is said to have burned with a flame of fire. When the party attempted to quench it, there was no fire there at all. ${ }^{106}$ This pillar of fire appeared again at her veiling by the bishop Machella, after which Brigid touched the altar post, which immediately budded forth with leaves. ${ }^{107}$ If Rochford was keen to omit some passages from Jocelin's life of Patrick that showed the saint inflicting harm on others, he did not allow this resolution to affect his treatment of Brigid. The story found in Capgrave, in which a man who prohibited Brigid's coach from passing through his fields is struck to the ground and dies, appears also in Rochford's version. ${ }^{108} \mathrm{~A}$ woman, who falsely and deliberately accused one of Patrick's bishops, namely, Broon, of fathering her child, was questioned by Brigid. When she refused to retract her claim, Brigid signed her mouth with the Sign of the Cross at which her head swelled up with a great tumour. Turning to the child, she then enquired of him who his father was, at which time the truth came out. ${ }^{109}$ Once again, if Rochford had made a concerted decision to excise cursing episodes from his lives, this should not have been included. Another lady, who had given apples to Brigid from her orchard and then chid her because she subsequently gave them away to poor lepers, provoked the saint into cursing her fruit trees so that they remained barren ever since. ${ }^{110}$ Rochford could quite easily have set aside these stories. Yet, he clearly decided in favor of their retention. ${ }^{111}$

${ }^{105}$ Rochford (B.B.), op. cit., pp. 118, 125, 129, 134.

${ }^{106}$ Ibid., p. 108.

${ }^{107}$ Ibid., pp. 110-111. Whitley Stokes argues that this pillar of fire is one example of the way heathen mythological legends became annexed to historical Christian saints: see Whitley Stokes (ed.), Three Middle-Irish bomilies on the lives of saints Patrick, Brigid and Columba (Calcutta, 1877), p. vii.

${ }^{108}$ Rochford (B.B.), op. cit., p. 124.

${ }^{109} \mathrm{Ibid}$., p. 132. Interestingly, although Rochford's version closely follows Capgrave, the version of Brigid's life found in the Leabhar Breac differs slightly in detail in this story, curiously rendering the cursing episode more benign. In the Leabhar Breac version Brigid does not make the Sign of the Cross over the woman's mouth but instead, over the child's mouth, at which he begins to tell the truth. Although it is recounted that a swelling assailed the woman's tongue, the direct link between Brigid's use of the Sign of the Cross and the woman's affliction no longer appears. In this case, then, it is the late medieval redactor, and not the Tridentine friar, who shows himself to be conscientious in portraying the actions of a saint in an appropriate manner: see Stokes (ed.), op. cit., p. 69.

${ }^{110}$ Rochford (B.B.), op. cit., p. 112.

${ }^{111}$ Rochford does omit one particular story that appears in both Capgrave and the Leabbar Breac. When Brigid was being offered the Eucharistic chalice by the bishop she saw 
It seems, then, that a reassessment of Rochford's reasons for abridging the lives of Ireland's three patrons is required. It may just be that the process of abridgement owed its origins to nothing more remarkable than the production of a more concise publication, which would convey to the reader a summary version of the saint's life. This was certainly the case with Rochford's treatment of the longer lives of Patrick and Columcille by Jocelin and Adomnán.

It is clear, then, that seventeenth-century versions of saints' lives did not always leave aside the miraculous and the vengeful elements of their subjects. It seems that the saints were understood by some to be as vengeful as ever. Perhaps the only difference between their exercise of rough justice in the earlier period and its seventeenth-century equivalent was that now the enemy was often more clearly defined, as cases concerning Reformers and their Reformed religion demonstrate. A life of St. Senan, written by a French hagiographer, Albert le Grand in 1629 at Plouzané, on the Breton coast, perfectly illustrates the marriage of Tridentine concerns and older ideas regarding vengeful sainthood that were suitably revamped and redirected at Protestants and their religion. Firstly, Senan is aptly depicted as a Counter-Reformation cleric. Having been chosen by St. Patrick to be his successor, he was quickly ordained as bishop. It is at this point in the story that the following comment is made:

As soon as he was consecrated, to the great joy of the whole island [Scattery Island, where he ministered], he immediately set to work and did so much that he eradicated all idolatry from Ireland, most scrupulously visiting his diocese and removing any abuse, which may have developed among the new Christian communities. ${ }^{112}$

St. Senan is portrayed, therefore, as a model for Tridentine prelates, conducting frequent visitations of his diocese and removing any abuses therein. However, a darker side to Senan's character is revealed in the recounting of a story relating to events in the late sixteenth century. The narrator relates how a "pseudo-bishop" of Limerick, appointed by

therein a vision of the head of a he-goat. The significance of the vision was revealed when the gillie confessed to having taken one of the goats that morning and eaten its flesh. Possibly Rochford omitted this tale because it recounted how one of Ireland's patron saints used to receive the Blood of Christ, and at a time when the Catholic Church was trying to argue its reasons for distributing the Eucharist under one species only, this might have caused confusion among the faithful. See Horstman (ed.), op. cit., p. 157.

${ }^{112}$ Liam de Paor, "La vie de Saint Sané: a seventeenth-century life of St. Senan," North Munster Antiquarian Journal, XXXV (1994), 48. 
Queen Elizabeth to instruct the people in the Protestant faith, wished to visit Scattery Island to persuade the people there to renounce the Pope and embrace reformed religion. Being fearful of visiting an island that was under the mighty protection of St. Senan, however, he sent one of his trusted ministers. Having arrived there, the minister ordered all the inhabitants to come to the church of Our Lady the following day to renounce the Pope and pledge allegiance to the Queen. In response, the islanders had recourse to St. Senan and besought his assistance. When the minister retired to bed that night, St. Senan, remaining invisible, entered his room and began to beat him violently with the back of his staff for over two hours. The next day the minister was in no fit state to keep his appointment with the people at Our Lady's Church. Some of the inhabitants that visited him informed the clergyman that he had suffered the punishment of St. Senan and duly advised him to abort his mission. Undeterred, however, the minister blasphemed against the saint, vowing to appear at the church the following day. That very night, St. Senan arrived for a second time into the minister's room, this time appearing in all his pontifical robes while wearing a mitre on his head and holding his crosier in his hand. Reprimanding the clergyman for his audacity, he dragged him from his bed and thrashed his body with the crosier until he was covered in wounds. By the time the saint disappeared the minister was found "all battered and broken, half drowned in his own blood." Leaving the island, he returned to Limerick and, four days after, "vomited his soul to the devil, still ensconced in his heresy." 113 Such an account, written in continental Europe at a time when there was concern to excise fantastic elements from Irish saints' lives in order to make them more acceptable to a church that aimed for stricter hagiographical standards, illustrates that seventeenth-century ideas regarding saints and their roles were, at best, a hybrid variety, bridging late medieval religion and Tridentine reform. ${ }^{114}$ The French hagiographer Albert le Grand in his compilation of the Life of St. Senan, drew on two

${ }^{113}$ Ibid., pp. 50-51.

${ }^{114}$ For the wider context of a hybrid Irish spirituality that was poised, like the doorkeeper Janus, with its eyes both on the past and the future see Salvador Ryan, "From late medieval piety to Tridentine pietism? The case of 17 th century Ireland," in Fred Van Lieburg (ed.), Confessionalism and Pietism: Religious Reform in the Early Modern Period ("Veröffentlichungen des Instituts für Europäische Geschichte Mainz," forthcoming); idem, "Popular Religion in Gaelic Ireland, 1445-1645" (2 vols.; unpublished Ph.D. thesis, National University of Ireland Maynooth, 2002);idem, "Bonaventura Ó hEoghusa's An Teagasg Críosdaidhe (1611/1614): a reassessment of its audience and use," Archivium Hibernicum, LVII (2004), 259-267. 
sets of ideas regarding sainthood. Interestingly, both sets managed to coexist in the minds of the most Tridentine of Catholic reformers.

The renewed interest in hagiography in the first half of the seventeenth century, especially by Irish scholars on the Continent, was nothing if not a complex affair. For this reason it cannot be explained in a simple manner without exploring the religious and political world from which it spawned. One cannot easily compare the objectives of individual compilers of saints' lives without some regard for the audience for whom they wrote, and the purpose for which they strove. The Irish Franciscan community at Louvain is a useful example of a body of individuals, often sharing a common building and a common faith, in addition to a collective regard for the lives of the saints, who, nevertheless, treated these saints very differently according to the audience they addressed. Aodh Mac Aingil alluded to one St. Patrick who not only banished snakes from Ireland but frogs also. ${ }^{115}$ Luke Wadding was apparently influential in excising the miraculous and far-fetched from the life of St. Patrick to be used in the new Roman Breviary while John Colgan, less than ten years later, was accused of leaving too many of these features in! ${ }^{116}$ The example of St. Patrick was highlighted by Aodh Mac Aingil in Sgátbán Shacramuinte na bAitbridbe (1618) far more than that of Brigid or Columcille, yet in Mícheál Ó Cléirigh's Martyrology of Donegal, compiled in 1630, seven pages are allotted to the account of Columcille's life as opposed to one page each for the lives of Brigid and Patrick. ${ }^{17}$ One cannot, for example, compare the treatment given to St. Patrick by John Colgan in his Triadis Thaumaturgae with that accorded the saint in the new Roman Breviary. While Colgan was concerned with collating all the available lives of Patrick into one dossier, Luke Wadding and his associates on the breviary reform commission were more interested in balancing conciseness and a version of the saint's life that would contain all the relevant details. While each work was published with a specific audience in mind and a particular purpose to achieve, it is also important to remember that these works were compiled by human agents with their own particular favorite saints. It should come as little surprise, then, to find Mícheál Ó Cléirigh, a native

\footnotetext{
${ }^{115}$ Sgátbán Shacramuinte na bAitbridbe, p. 29. This claim is also made by the bardic poet, Philip Bocht Ó hUiginn (d. 1487); see Lambert McKenna (ed.), Pbilip Bocht Ó bUiginn (Dublin, 1931), p. 10, v. 5.

${ }^{116}$ Cunningham and Gillespie, op. cit., pp.90-91; Sharpe, op. cit., p. 60.

${ }^{117}$ James Hawthorn Todd and William Reeves (eds.), The martyrology of Donegal: $a$ calendar of the saints of Ireland (Dublin, 1864), pp. 150-165, 34-37, 78-81.
} 
of Donegal, extolling at length the virtues of Columcille in his Martyrology, leaving Patrick rather underrated, while Aodh Mac Aingil, hailing from Down, eulogizes Patrick at every opportunity, expressing great familiarity with the localities associated with his penances. Yet, promotion of the three principal saints of Ireland clearly received a new impetus in the seventeenth century. One need only compare the entries for the year 493 (traditionally held to be the year of St. Patrick's death), in the Annals of Ulster and the Annals of the Four Masters, to notice the greater importance accorded the saint in the seventeenth century. The entry for the former is quite brief:

Patrick, arch-apostle or archbishop and apostle of the Irish rested on the 16th of the calends of April in the 120th year of his age, in the 60th year after he had come to Ireland to baptise the Irish. ${ }^{18}$

The seventeenth-century annals, prepared by Mícheál Ó Cléirigh and his associates, provide a much fuller treatment of the national patron:

Patrick, son of Calphurn, son of Potaide, archbishop, first primate and chief apostle of Ireland, whom Pope Celestine first had sent to preach the Gospel and disseminate religion and piety among the Irish [was the person] who separated them from the worship of idols and spectres, who conquered and destroyed the idols which they had for worshipping; who had expelled demons and evil spirits from among them, and brought them from the darkness of sin and vice to the light of faith and good works, and who guided and conducted their souls from the gates of Hell (to which they were going) to the gates of the Kingdom of Heaven. It was he that baptised and blessed the men, women, sons and daughters of Ireland, with their territories and tribes, both [fresh] waters and sea inlets. It was by him that many cells, monasteries and churches were erected throughout Ireland; seven hundred churches were their number. It was by him that bishops, priests and persons of every dignity were ordained; seven hundred bishops and three thousand priests [was] their number. He worked so many miracles and wonders that the human mind is incapable of remembering or recording the amount of good which he did upon earth. When the time of St. Patrick's death approached, he received the Body of Christ from the hands of the holy bishop, Tassach, in the 122nd [year] of his age and resigned his spirit to Heaven. ${ }^{119}$

${ }^{118}$ B. Mac Carthy (ed. and trans.), Annala Uladb-Annals of Ulster, otherwise Annala Senait; A chronicle of Irish affairs, A.D. 431-1131; 1155-1541 (4 vols.; Dublin, 1887-1901), I, 493.

${ }^{119}$ John O'Donovan (ed.), Annála rioghachta Éreann:Annals of the Kingdom of Ireland by the Four Masters, from the earliest period to the year 1616 (7 vols.; Dublin, 1851), I, 493. 
It is fallacious to speak of only one "reworking of the saints" in the first half of the seventeenth century. As observed above, the saints were used in several different ways for a variety of purposes, and by a diverse number of individuals, thus making the study of their lives during this period a fascinating but challenging task. 